Polona Kelava, Andragoški center Slovenije

\title{
KOMUNIKACIJA IN PISNE SPRETNOSTI (2. del) \\ Spreminjajoče se zahteve pismenosti
}

\section{POVZETEK}

Prispevek se osredotoča na povezanost ravni pisnih spretnosti posameznika z njegovo stopnjo izobrazbe, pri čemer ugotavljamo, da se v izobraževanje odraslih pogosteje vključujejo višje izobraženi. Na ta način se njihove izhodiščno ustreznejše pisne spretnosti povečujejo, nižje izobraženi pa na račun neizpopolnjevanja znanj za njimi vse bolj zaostajajo. Slovenija po izsledkih raziskav pismenosti tako v primerjavi z uvrstitvijo med razvite države kor tudi glede na druge kazalce socialnega razvoja najvidneje zaostaja, glede na izobrazbeno strukuro dejavnih in nedejavnih odraslih v izobraževanju pa se izboljšanje ravni pisnil spretnosti zdi precej nedosegljivo.

Ključne besede; izobraževanje odraslih, pismenost, stopnja izobrazbe, razširjena vsebina pismenosti

V prejšnji številki smo govorili o razširjenosti sredstev komunikacije in vplivu stopnje izobrazbe na njihovo uporabo, pri čemer smo posebej izpostavili dostop do interneta. Razlike med njegovimi uporabniki dnevno naraščajo, najvidneje jih ločuje ravno izobrazba.

Višja stopnja izobrazbe praviloma prinese tudi ustreznejše pisne spretnosti, katerih zahtevana vsebina se vsakodnevno širi in bogati, zato je njihova nadgradnja še toliko nujnejša. Obstoječim komponentam pismenosti smo dodali novi razsežnosti, novi zahtevi "medijsko pismenost" (Erjavec, 1999a in 1999b) in "informacijsko-komunikacijsko pismenost" (ki se sicer nekoliko prekrivata, vendar ju je neustrezno povsem enačiti), ki odrasle delita še bolj enopomensko od same pismenosti, slednja po brezkompromisnih načelih digitalnega razkoraka. Pismenost je v izobraževanju odraslih nekoliko običajnejša tema kot "informacijsko-komunikacijska" pi- smenost, njene pojavnosti pa smo se prav tako začeli zavedati šele relativno pred kratkim (prim. Drofenik in Ivančič, 1992; Krajnc, 2001). Podobni sta sì v tem (čeprav prva vsebuje tudi drugo), da se njune zahteve izjemno hitro spreminjajo in zato tej dinamiki lažje sledijo višje izobraženi (kar bomo za prvo šele pokazali), ter da nista stalni in dokoněno opredeljivi, S pismenostjo bomo torej spregovorili o še bolj vseobsegajoči (ne)kompetencí za učinkovito delovanje $\mathrm{v}$ vsakodnevnem življenju, kot jo tistim, ki so na eni ("spodnji") strani njegove delitve, povzroča digitalni razkorak.

Preden se posvetimo stopnji izobrazbe kot precej zanesljivi pokazateljici stopnje pismenosti posameznika, se pomudimo pri terminologiji pismenosti, okrog česar je bilo $\mathrm{v}$ novejših objavah pri nas sicer že veliko govora, Razlog za "postanek" je v opredelitvi vsebine pismenosti, o kateri smo govorili že v 
prejšnjem delu in bomo znova tudi $v$ tem prispevku.

Izraz "funkcionalna pismenost" naj bi bil neprimeren, zato naj bi se po novem uporabljal zgolj izraz "pismenost", misleč pri tem na "ravni" oziroma "stopnje" pismenosti. Na problem uporabe izraza "funkcionalna pismenost" opozarja E. Možina (1999), ki poleg terminoloških vidi tudi težave $v$ metodologiji merjenja pismenosti. (Prim. tudi OECD, 2002) V novejših raziskavah pismenosti se merijo tri vrste (področja) pismenosti, ki jih je pri nas merila raziskava Pismenost odraslih in udeležba v izobraževanju odraslih (Andragoški center Slovenije, 1998), in so tudi mednarodno primerljive (Raziskava IALS - International adult literacy survey, OECD).

$\breve{C}$ e beseda pismenost potemtakem predstavlja zaokroženo celoto obvladovanja ali neobvladovanja teh treh vrst pismenosti, bi bil za potrebe naše predstavitve problematike primernejši razšrirjen pojem. Ustrezno rešitev vidimo $v$ uporabi izraza "funkcionalna pismenost", ki smo ga zasledili tudi še v novejših objavah, in imamo pri tem $s$ funkcionalno pismenostjo $\mathrm{v}$ mislih najbolj vsestransko (vseobsegajočo) usposobljenost za aktivno, učinkovito vključevanje $\mathrm{v}$ družbo ter za obvladovanje zahtev tako delovnega mesta kot osebnega življenja. (Prim. Možina, 1999.) Pri "funkcionalni pismenosti" poudarjamo predvsem "funkcionalnost" znanj in načinov njihove uporabe, "uporabnost" znanj v situacijah, s katerimi se posameznik vsakodnevno spoprijema. "Funkcionalna pismenost" nam pove, "kako kakovostno znajo odrasli uporabiti informacije, ki so jim na voljo, da bi 'funkcionirali' $v$ družbi in gospodarstvu" (OECD, 2002). Širše opredelitve pismenosti, ne zgolj $\mathrm{z}$ andragoškega vidika, temveč različnih humanističnih in družboslovnih ved, raziskuje tudi Janko Spreizerjeva (1998). V nasprotju z obstojem "ene" pismenosti ob povzemanju po različnih
V operativnem smislu merimo pismenost na treh področjih, od katerih vsebuje vsako skupen niz spretnosti, ki ustrezajo raznolikim nalogam. Besedilna pismenost predstavlja znanje in spretnosti, ki so potrebni za razumevanje in uporabo informacij iz besedil, kot so članki, zgodbe, poezija in proza. Dokumentacijska pismenost pomeni znanje in spretnosti, ki so potrebni, da najdemo in uporabimo informacijo, ki je vsebovana v različnih oblikah, vključujoč prijavo na razpis, čeke za plače, vozne rede, zemljevide, tabele in slikovne prikaze, $\mathrm{Ra}$ čunska pismenost zahteva od posameznika znanje in spretnosti, ki so potrebni za uporabo računskih operacij, posamezno ali v nizu, za uporabo številk v tiskanih besedilih, na primer vodenje bančnih izpiskov, izračunavanje napitnine, izpolnjevanje naročila ali izračunavanje obresti za posojilo na podlagi oglasa. (Tuijnman, 2001, str. 70)

avtorjih ugotavlja prisotnost "mnogoterih" pismenosti (prav tam). Navezujemo se predvsem na to, da mora biti vsebina (funkcionalne) pismenosti, pa naj gre za merjenje vsebine (funkcionalne) pismenosti z raziskavami ali impliciranje vsebine (funkcionalne) pismenosti s programi opismenjevanja, vsakokrat kompatibilna s konkretnim okoljem, v katerem živijo posamezniki, ki jih to zadeva. $\mathrm{Na}$ ta način se lahko pokažejo razlike med "golo" pismenostjo in njeno funkcionalno vrednostjo, ki bi po pričakovanjih morala predstaviti manjša odstopanja in manj odraslih na najnižjih ravneh pismenosti, kot jih nakazujejo izsledki raziskav, ki so ugotavljale obvladovanje bolj splošnih vsebin in spretnosti. Pri tem se zavedamo, da bi bilo tako natančne raziskave težko, če ne nemogoče izvesti, zato se bomo oprli na izsledke raziskave Pismenost odraslih in udeležba v izobraževanju odraslih, ki jo je Andragoški center izvedel leta 1998 in nam je tudi upoštevaje splošnejšo opredelitev pismenosti - postregla s preveč zaskrbljujočimi podatki. Predvidevamo tudi, da morajo pripadniki slovenske družbe na razvojni stopnji, na kateri je družba danes, in predvsem v skladu s smerjo, v katero si prizadeva s povezovanjem
A) 9,9 ) 
"Globalna" in "lokalna" pismenost v multilaterarne (gospodarske) integracije, vsi, skoraj brez izjeme, imeti neka splošna znanja in spretnosti, brez katerih se bodo dobesedno vsak dan težje prebijali skozi Življenje in se brez njih ne bodo mogli prilagajati novonastalim zahtevam vsakdana.

$\mathrm{S}$ tem argumentom ocenjujemo kot veljavne tudi izsledke raziskave, ki jo bomo najpogosteje navajali, in potrjujemo obstoj "globalne" pismenosti (v nasprotju z "lokalno"). (Žal lahko na tem mestu pripomnimo tudi, da Slovenija na področju pismenosti izrazito zaostaja za razvitimi državami Evrópe in Amerike; Možina, 2000.) O pismenosti, ki sega onstran izobraževanja odraslih, se opredeli tudi Berlogar (2000), ki ji pred andragoško pripisuje še etično, politično in ekonomsko razsežnost.

\section{Posamezniki živijo od tega, kako zna- jo komunicirati.}

Pismenost, ki jo omenjamo, pomeni torej pismenost $\mathrm{v}$ mnogo širšem smislu, kot bi jo bilo sploh mogoče izmeriti $\mathrm{v}$ skladu $\mathrm{z}$ njeno dnevno spreminjajočo se vsebino; to smo nakazali v prvem delu prispevka. Pismenost, o kakršni je v izobraževanju odraslih najpogosteje govora, ima vsaj navidez malo skupnega $\mathrm{z}$ dostopom do najsodobnejših sredstev komunikacije, razširjen pojem pa bi utegnil ustrezati svoji tesni prepletenosti z dostopom do najrazličnejših virov znanja.

\section{RAVEN PISMENOSTI V SLOVENIJI}

Omenili smo že, da število sredstev komunikacije samo po sebi ne pomeni veliko, če jih njihovi "naslovniki" ne znajo uporabljati. Komunikacija z drugimi je zato poglavitnega pomena; če se namreč življenje ne zapolni $\mathrm{z}$ ustreznimi intelektualnimi ( $\mathrm{v}$ mnogočem komunikacijskimi, op. P. K.) aktivnostmi, se tudi naknadno pridobljena funkcionalna pismenost zabriše (Krajnc, 1992, str. 9).
(Prim. tudi Drofenik in Ivančič, 1992, str. 1) $\mathrm{V}$ tem smislu je znano tudi, da se morajo znati ljudje, če želijo biti kar najkoristnejši na trgu delovne sile pa tudi širše v družbi, učiti na načine, ki jih lahko praktično izkoriščajo skozi vse življenje. Predvsem morajo imeti skupek splošnih kompetenc, ki jih preskibijo $s$ stalnim učenjem in z zmožnostjo prilagajanja novim kontekstom (Education ..., 2001, str. 89,90 ). V informacijski družbi ali postindustrijski družbi je tako proizvodnjo zamenjalo komuniciranje.

Posamezniki živijo od tega, kako znajo komunicirati (Krajnc, 2001, str. 66). Z raziskavo Pismenost odraslih in udeležba $v$ izobraževanju odraslih se je pokazalo, da bolj izobraženi "bolj kakor drugi odpirajo prostor za delovanje manj strukturiranim in manj formaliziranim oblikam izobraževanja" (Mirčeva in Radovan, 2001, str. 93), torej s pridom izkoriščajo tudi sredstva komunikacije v izobraževalne namene, verjetno pa razen tega razpolagajo $\mathrm{z}$ ustreznejšimi načini učenja.

Odkrivanje in odpravljanje neustreznih pisnih spretnosti odraslih (Prim. Dovžak, 1993) je med ključnimi strateškimi usmeritvami strategije gospodarskega razvoja Slovenije na področju izobraževanja (Drofenik in sod., 1998, str. 283), kar nedvomno kaže na resnost problemá tudi pri nas.

Funkcionalna pismenost odraslih je "določena sposobnost in način obnašanja, zmožnost razumeti in uporabiti napisane informacije $\mathrm{v}$ dnevnih aktivnostih, doma, na delovnem mestu in $v$ skupnosti, da bi dosegli svoje cilje ter razvili svoje znanje in potenciale" (OECD, 2002). Zato so razlike $v$ ravneh pismenosti pomembne tako ekonomsko kot družbeno: pismenost med drugim vpliva na kakovost ter fleksibilnost dela, zaposlitev, možnosti za usposabljanje, zaslužek ter širšo udeležbo v civilni družbi (prav tam). 


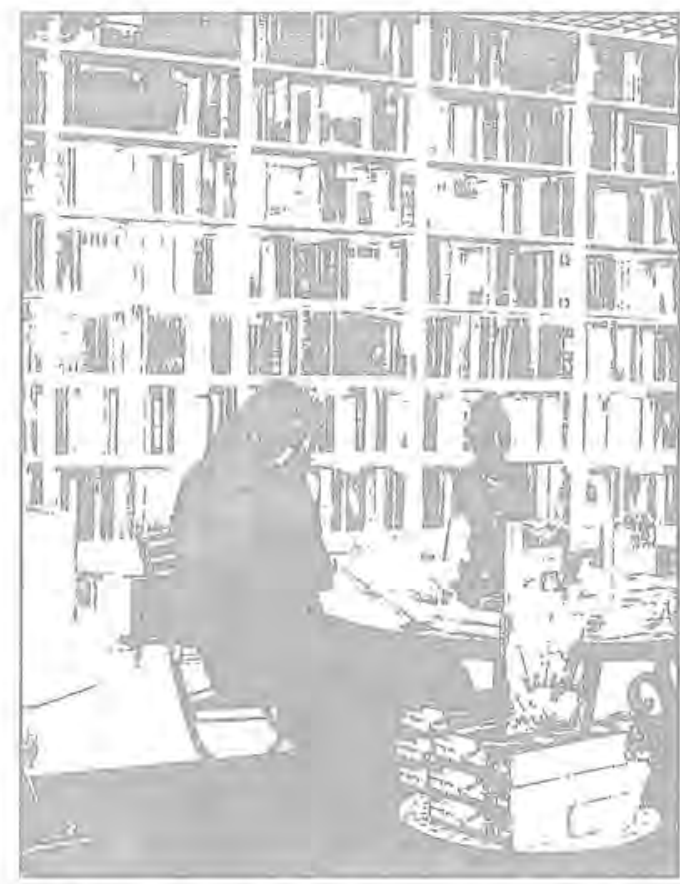

In če vse to velja za pismenost ožje ali le za besedilno pismenost, želimo pokazati, kako se različne "vrste" pismenosti ter področja, na katera vplivajo, med seboj tesno prepletajo. Predpostavljamo, da odraslim, ki dosegajo najnižje stopnje pismenosti, njihova nezmožnost za polno vključevanje $\mathrm{v}$ družbene procese onemogoča, da bi okoli sebe prepoznavali in izrabljali vire učenja ali pa jim otežuje uporabo sredstev komunikacije, kar jih dodatno omejuje $v$ primerjavi z ostalimi ter jih odriva na rob socialnega življenja. Novejše raziskave pismenosti, ki so bile po metodologiji OECD izpeljane v mnogih državah, tudi v Sloveniji leta 1998 (Mohorčič Špolar in sod., 2001), ugotavljajo tako besedilno kot dokumentacijsko in računsko pismenost. Poleg tega posameznikov ne delijo zgolj na pismene in nepismene, temveč dobljene rezultate porazdelijo na več ravni, kar omogoča realnejšo sliko pismenosti v posamezni družbi.

$\mathrm{V}$ mednarodnih raziskavah pismenosti odraslih se uporabljajo sodobne metode za merjenje pisnih spretnosti; tako se odrasli na pod-

lagi rezultatov, ki so jih dosegli, porazdelijo na pet ravni pismenosti. Prva raven pismenosti pomeni, da ima posameznik zelo slabe sposobnosti. (Posameznik, na primer, iz navodila za uporabo ne zna izračunati količine zdravila, ki jo mora dati otroku.) Za posameznike, ki dosegajo drugo raven pismenosti, je značilno, da se znajo spoprijeti le z vsebino, ki je preprosta, jasno izražena in naloge niso preveč zapletene, kar prav tako kaže na nizko stopnjo njihovih spretnosti. (Ti posamezniki so razvili spretnosti, s pomočjo katerih se spoprijemajo s svojimi vsakodnevnimi zahtevami po pismenosti, vendar pa se težko spopadejo z novimi nalogami, kot je na primer učenje novih spretnosti na delovnem mestu.) Tretja raven predstavlja soliden minimum za posameznike, da so kos zahtevam vsakodnevnega življenja in dela $v$ današnji zapleteni in napredni družbi. V splošnem predstavlja stopnjo spretnosti, ki se pričakujejo od diplomantov višje sekundarne stopnje izobraževanja oziroma se zahtevajo za vpis v terciarno izobraževanje. Kot najvišji dve ravni zahteva zmožnost integracije večjega števila virov informacij in reševanje kompleksnejših problemoy. Nekdo, ki je zasedel četrto ali peto raven pismenosti, je zmožen višje stopnje spretnosti predelave informacij. (OECD, 2002)

$\mathrm{Z}$ ozirom, da šele umestitev na tretjo raven pismenosti (pa naj gre za besedilno, dokumentacijsko ali računsko pismenost) zagotavlja uspešno vključevanje posameznika $\mathrm{v}$

\section{Pismenost kot zmožnost prede- lave informacij.}

družbo in $\mathrm{s}$ tem tudi $\mathrm{v}$ izobraževanje (Radovan, 2001, str. 139), lahko rečemo, da prva in druga stopnja pismenosti ne pomenita ustrezne usposobljenosti za vsakdanje potrebe posameznika $v$ svetu dela ali v osebnem življenju.

V Sloveniji je leta 1998 prvi dve ravni besedilne pismenosti doseglo 76 odstotkov posameznikov, 73 odstotkov jih je doseglo prvi

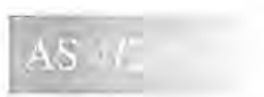


dve ravni dokumentacijske pismenosti in 65 odstotkov prvi dve ravni računske pismenosti (Raziskava Pismenost odraslih in udeležba v izobraževanju, Ljubljana: Andragoški center Slovenije, 2000; v Poročilo ..., 2001, str. 110). $\mathrm{Ti}$ podatki ne govorijo $\mathrm{v}$ prid zmožnostim izobraževanja večine posameznikov, zato nas razen obsega funkcionalne pismenosti zanima, kako se stopnje dosežene pismenosti povezujejo s stopnjo izobrazbe posameznika.

Leta 1998 so bili posamezniki, ki so dosegli 1. in 2 , raven besedilne pismenosti, vsi odrasli z nedokončano osnovno šolo (100 odstotkov). Med odraslimi $\mathrm{z}$ dokončano osnovno šolo tretje ravni besedilne pismenosti ni doseglo 89 odstotkov, med posamezniki z 1- do 2-letno poklieno šolo 97 odstotkov, s triletno poklicno šolo pa 88 od- stotkov posameznikov. Med odraslimi, ki niso dosegli zadovoljivih rezultatov $\mathrm{v}$ besedilni pismenosti, jih je 64 odstotkov imelo dokončano srednjo šolo, "le" 43 odstotkov je bilo najvišje izobraženih. (Radovan, 2001, str. 138) Kot vidimo, stopnja besedilne pismenosti pri odraslih s stopnjo izobrazbe raste.

Ustrezne ravni dokumentacijske pismenosti ni dosegel nihče med odraslimi z nedokončano osnovno šolo. Med posamezniki z dokončano osnovno šolo je bilo 83 odstotkov odraslih, ki so dosegli prvi dve ravni dokumentacijske pismenosti, med posamezniki z 1 - do 2-letno poklicno šolo 91 odstotkov, s triletno poklicno šolo pa 84 odstotkov. Zahtev tretje ravni dokumentacijske pismenosti ni doseglo 60 odstotkov odraslih s srednješolsko izobrazbo in 39 odstotkov odraslih z višješolsko izo-

\section{Grafikon 1:}

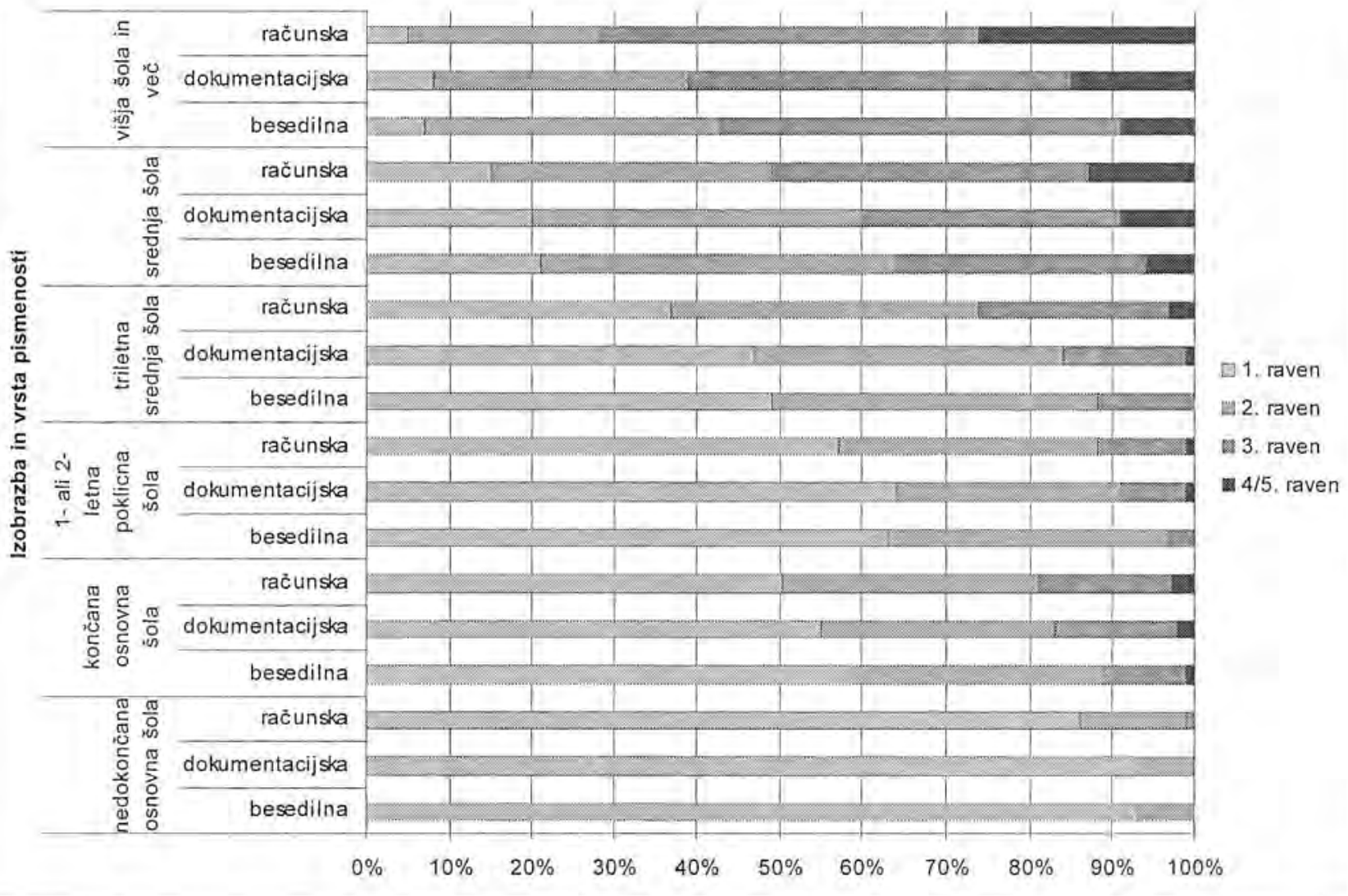


brazbo ali še višjo.

Odraslih, ki niso dosegli zadovoljivih rezultatov v računski pismenosti in hkrati niso dokončali osnovne šole, je bilo leta 199899 odstotkov, med tistimi, ki so jo končali, 82 odstotkov, med posamezniki s končano 1- do 2-letno poklicno šolo pa več, 88 odstotkov. Z osnovnimi računskimi problemi se ne spopadajo dovolj učinkovito tri četrtine, tj. 74 odstotkov odraslih s poklicno šolo ter polovica (49 odstotkov) srednješolsko izobraženih odraslih, pridružuje se jim 28 odstotkov odraslih z višjo šolo ali več (prav tam). (Grafikon 1)

Med področji pismenosti so se odrasli najbolje odrezali v računski pismenosti, vendar tudi tu ne zadovoljivo. Ugotavljamo, da izobrazba odločilno vpliva na funkcionalno pismenost, saj se "z višjo izobrazbo povečuje delež odraslih na višjih ravneh pismenosti," (Radovan, 2001, str. 138). Da na pismenost posameznika vplivajo njegov socialnoekonomski položaj, stopnja izobrazbe in izkušnje pri delu, so zaključili tudi v Organizaciji za ekonomsko sodelovanje in razvoj. (Literacy ..., 1997) Pismenost naj bi bila pomembna za "ekonomsko produktivnost, zdravje in splošno dobro ter za socialno kohezijo v modernih družbah" (pray tam, str. 85). Funkcionalna pismenost je zato morda več od seštevka besedilne, dokumentacijske in računske pismenosti, pridružujejo se ji vsakokrat nove vsebine, ki jih je potrebno znati obvladati. To so sicer najkonkretnejši podatki, s katerimi razpolagamo, $\mathrm{ki}$ pa se dovolj prepričljivo povezujejo $\mathrm{z}$ doseženo stopnjo izobrazbe posameznika, V mednarodni primerjavi se je namreč pokazalo, da je "daleč najpomembnejša determinantá pismenosti v Sloveniji ravno dosežena izobrazba" (Tuijnman, 2001, str. 75).

Nižje ravni funkcionalne pismenosti se tako izrazito navezujejo na določene skupine odraslih (ciljne skupine) ali njihove posamez- ne značilnosti. A. Krajnc ugotavlja, da se odrasli, ki ne dosegajo zadovoljivih rezultatov $v$ funkcionalni pismenosti, "kopičijo" $v$ nekaterih kategorijah, kot so brezposelni, trajno brezposelni, čakajoči za preusposabljanje, prezgodaj upokojeni itd. (Krajnc, 1992, str. 10). Slovenija se, na primer, uvršča med države, kjer je $v$ skupini $z$ najnižjo stopnjo funkcionalne pismenosti dvakrat več brezposelnih kot med odraslimi s srednjo in visoko stopnjo funkcionalne pismenosti (Education

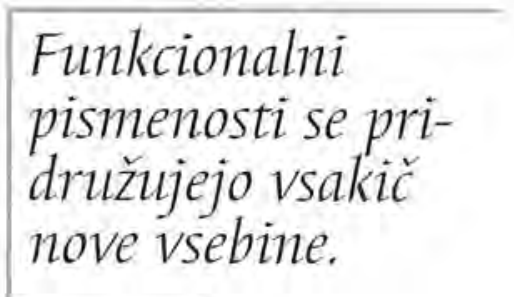
..., 2001, str. 90). Ker dajejo večje možnosti uporabe spretnosti pismenosti le poklicni položaji pri vrhu póklicne hierarhije (Ivančič, 2001 , str. 49-53) - to so potrdili tudi izsledki raziskave pismenosti odraslih (prav tam) -, je tudi za zaposlene tveganje za brezposelnost pri odraslih, ki dosegajo slabše rezultate v pismenosti, mnogo večje. Tudi sicer so avtorji mednatodne raziskave pismenosti ocenili, da imajo delovne izkušnje pozitivni učinek na zaslužek, oboje pa se povezuje z izobrazbenimi kvalifikacijami in pisnimi spretnostmi (Literacy ..., 1997, str. 51). Tako imajo odrasli z doseženimi nizkimi ravnmi pisnih spretnosti "pomembno manj priložnosti za delo" (Education ..., 200I, str. 90).

Slovenija je specifična še po nečem. Glede na mesto, ki ga med državami dosega po odstotku funkcionalno pismenih, se ravno $v$ funkcionalni pismenosti uvršča mnogo nižje kot po drugih kazalcih socialnega razvoja. (Ekonomsko ..., 2000, str. 9)

\section{VKLJUČEVANJE V IZOBRAŽEVANJE $Z$ OZIROM NA PISMENOST}

Značilnosti nižje izobraženih, med katerimi je največ posameznikov $\mathrm{z}$ neustreznimi stopnjami pismenosti, tudi nakazujejo, da je njihov položaj pri vključevanju v izobraževanje otežen in da lahko doseganje nizkih ravni 
Po odvisnosti funkcionalne pismenosti od stopnje izobrazbe odraslih bi lahko sklepali, da se odrasli, ki dosegajo nezadostno raven pismenosti, mnogo manj izobražujejo kot odrasli, ki v pismenosti dosegajo boljše rezultate. S primerjalno študijo držav Kanade, Švice (nemški in francoski del), ZDA, Nizozemske, Švedske in Poljske so pokazali, da imajo pisne spretnosti velik vpliv na udeležbo $v$ izobraževanju odraslih; višja kot je dosežena raven pisnih spretnosti, pogostejša je udeležba v izobraževanju odraslih. (Bélanger in Valdivielso, 1997, str. 17)

pismenosti vključevanje $v$ izobraževanje preprečuje.

$\mathrm{V}$ veljavnost te trditve za naše področje se lahko prepričamo $\mathrm{z}$ izsledki raziskave $\mathrm{Pi}$ smenost odraslih in udeležba v izobraževanju odraslih, ki govorijo o dejanskem vključevanju posameznikov $v$ izobraževanje glede na njihovo stopnjo pismenosti. Dejavni odrasli so se v letu 1998 po stopnjah pismenosti izkazali takole: odraslih, ki ne dosegajo zadovoljivih rezultatov $\mathrm{v}$ besedilni pismenosti, je bilo 64 odstotkov, v dokumentacijski 57 odstotkov in $v$ računski 47 odstotkov. Več odraslih, ki dosegajo prvi dve ravni pismenosti, je bilo istega leta med morebitno dejavnimi odraslimi: zadostnih znanj $v$ besedilnih nalogah ni moglo pokazati 79 odstotkov odraslih, v dokumentacijski pismenosti se ni izkazalo 76 odstotkov, v računski pa 66 odstotkov odraslih. Med nedejavnimi v izobraževanju je, kot smo predvidevali, največ posameznikov $\mathrm{z}$ neustreznimi stopnjami pismenosti: zahtev besedilne pismenosti ni zadovoljilo 95 odstotkov, dokumentacijske 92 odstotkov, računske pa 88 odstotkov nedejavnih odraslih. (Radovan,

\section{Grafikon 2:}

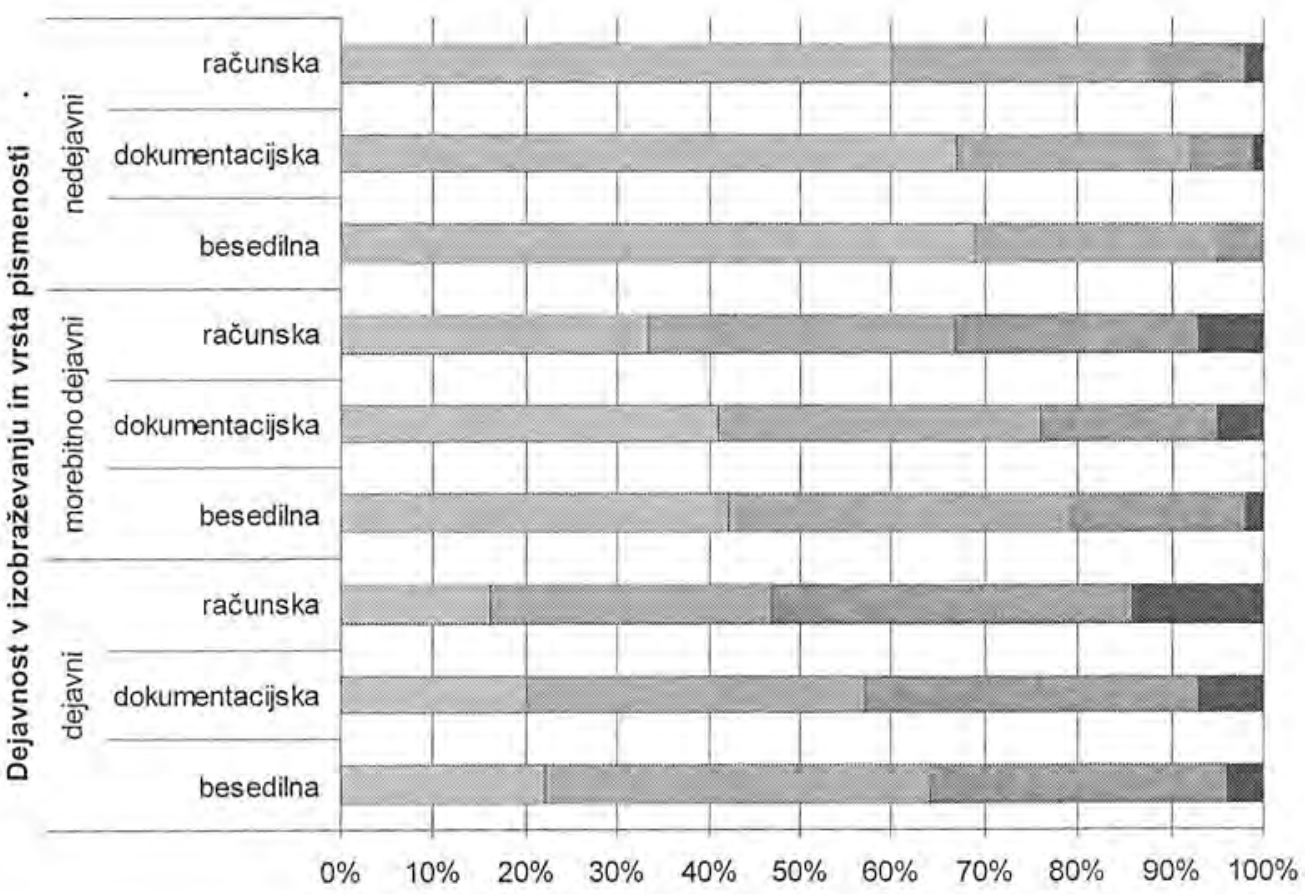

71. raven

는 raven

¿3. raven

a $4 / 5$, raven 


\section{1, str. 140) (Grafikon 2)}

Zaradi tega napovedujemo, da se tudi razlike $\mathrm{v}$ funkcionalni pismenosti povečujejo, saj je med odraslimi, ki so dejavni v izobraževanju, več posameznikov, ki dosegajo višje ravni pismenosti kot $\mathrm{v}$ kateri od ostalih skupin glede na preteklo udeležbo $\mathrm{v}$ izobraževanju. Razlike se gotovo poglabljajo, če se eni skupini odraslih znanja ne obnavljajo in njihova trenutna znanja večinoma prav tako niso ustrezna, drugi pa so že usposobljeni za aktivno in učinkovito delovanje $v$ družbi ter se $v$ teh spretnostih nenehno izpopolnjujejo in znanja nadgrajujejo.

Findeisnova (1998), denimo, na primeru specifičnosti uporabe različnih "ravnin" francoskega jezika pokaže ovirano mobilnost med "sloji" prebivalstva, ki se ločujejo že po različnih stopnjah funkcionalne pismenosti. To potrjuje tudi dejstvo, da neustrezne pisne spretnosti staršev porajajo neustrezne pisne spretnosti otrok (Krajnc, 1993, str. 8-10), višji in nižji socialni sloj se ločujeta glede izrabe prostega časa in deleža dnevnih aktivnosti, namenjenih izobraževanju (prav tam, str. 10-13), saj intenzivnost aspiracij za izobraževanje praviloma določijo že najnežnejša leta. $\mathrm{K}$ pridobivanju, ohranjanju ali izgubi pisnih spretnosti prav tako prispevajo zaposlitev in vrsta dela, ki ga posameznik opravlja, raba pisnih spretnosti pri delu ter udeležba $v$ izobraževanju odraslih. (Možina, 2000, str. 34) Odgovornosti za možnosti dostopa do pismenosti ( $v$ nasprotju $\mathrm{z}$ lastnimi zmožnostmi) pa naj ne bi pripisovali zgolj posamezniku, temveč družbi. Selekcijo in izključevanje (iz pismenosti) usmerja volja družbenih elit, temelječih na moči pozicije (Berlogar, 2000, str. 117). V tem smislu reprodukcija družbenih razmerij poteka tudi skozi pismenost. Ker se družbe ohranjajo (in ne spreminjajo) z vzdrževanjem ravnotežja med bogatimi in revnimi, izobraženimi in neizobraženimi, tistimi, ki zadovoljujejo zahteve funkcionalne pismenosti, in drugimi, ki jih ne, ipd., tudi od programov opismenjevanja ne pričakujemo temeljitejšega preobrata. (Prim. Heyneman, 1992)

Iz vsega povedanega $v$ zgornjem odstavku lahko zaključimo, da se razlike $v$ funkcionalni pismenosti med posamezniki povečujejo. Spremenjena socioekonomski in sociokulturni položaj posameznika pa ne pomenita le posledice funkcionalne pismenosti, temveč ju v strokovni literaturi označujejo celo kot vzrok neustreznih ravni funkcionalne pismenosti (Drofenik in Ivančič, 1992, str. 2, 3), O generiranju in poglabljanju že obstoječe družbene razslojenosti na tej osnovi razpravlja tudi Mirčeva (2000), pri čemer ni zanemarljivo, da je med odraslimi $\vee$ Sloveniji $z$ zadostnimi pisnimi spretnostmi in tistimi, katerih spretnosti so nezadostne, razlika mnogo večja kot v večini držav članic OECD (Možina, E., 2000, str. 39).

Poglabljanje razlik, kot da ni dovolj zaskrbljujoče, lahko pokažemo še na primeru regionalnih razlik $v$ pismenosti. Tako kot v izobrazbeni strukturi, se tudi tu kažejo velike razlike. V primerjavi odstotka posameznikov, ki dosegajo

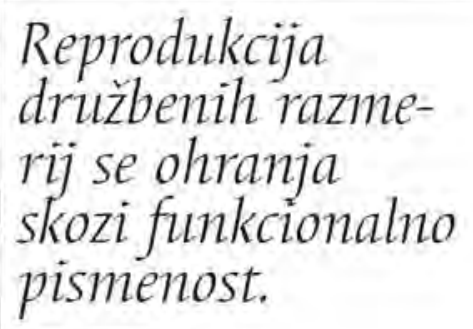
prvo stopnjo besedilne pismenosti, in bruto vpisnega količnika $\mathrm{v}$ izobraževanje najbolj izstopa osrednjeslovenska statistična regija. Pri vseh tovrstnih primerjavah velja opozoriti, da se upošteva samo dosežena 1. raven in to samo besedilne pismenosti (prim. Hanžek, 2000, str. 94, Ekonomsko ..., 2000, str. 9). Pokazali smo že, da niti dosežena 2. raven ne zadostuje za ustrezno delovanje posameznika $v$ družbi, zato bi bili pravi rezultati takšnih primerjav morda še bolj zaskrbljujoči. Prav tako bi bilo mogoče smiselno primerjati več vrst pismenosti, ne le besedilne. Poleg osrednjeslovenske dokaj ugodne vrednosti dosegata še gorenjska in goriška regija, medtem ko imajo najnižjo stopnjo besedilne 


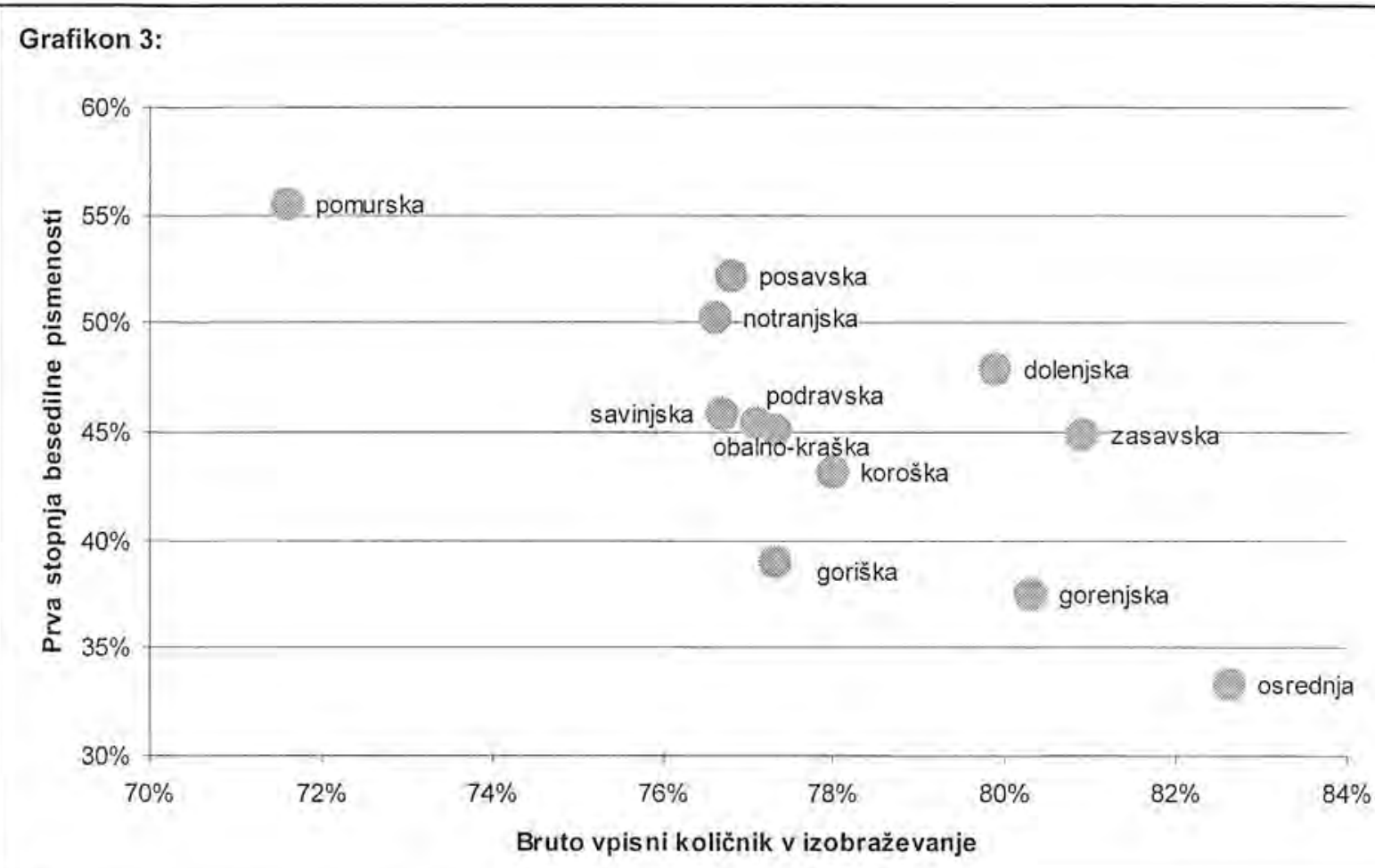

pismenosti in najnižji bruto vpisni količnik v izobraževanje pomurska, posavska in notranjska regija. (OECD - ACS in SURS; v Ekonomsko .., 2000, str. 9)

Tudi povezanost znanja $\mathrm{z}$ zdravjem in ekonomsko močjo je velika. To dokazujejo korelacijski koeficienti med nizkimi stopnjami funkcionalne pismenosti odraslih in pričakovano dolžino življenja $(-0,7590)$, bruto domačim proizvodom $(-0,71805)$ in šolajočimi se v regiji $(-0,54345)$. Podatki kažejo, da je $v$ ekonomsko manj razvitih območjih Slovenije tudi manj znanja, kar pomeni, da se bodo ob pomanjkanju ustrezne razvojne poli- tike razlike med regijami še povečevale (Ekonomsko ..., 2000, str. 9).

\section{SKLEP}

Uporaba informacijsko-komunikacijske tehnologije pa tudi uporaba ostalih sredstev komunikacije pomeni dodatno, razmeroma novo komponento vrednotenja funkcionalne pismenosti, ki z očitnimi razlikami v dostopu dodatno socialno razslojuje. Ugotovili smo, da množičnost uporabe sredstev komunikacije pogojuje stopnja izobrazbe, kar se najneposredneje povezuje tudi $\mathrm{z}$ doseženimi

Ravni posameznih pismenosti, ki ljudem omogočajo "normalno" vključevanje v družbo in učinkovito "funkcioniranje" v njej, pogojujejo tudi možnosti pri vključevanju v izobraževanje in kakovost njegove izvedbe. Tako so posamezniki z nezadostnimi stopnjami pismenosti, ki imajo praviloma slabše izobrazbeno izhodišče, zaradi omejitev tako pri vključevanju v izobraževanje kot pri uporabi sredstev komunikacije prikrajšani za napredovanje na tem področju in se sčasoma vse bolj oddaljujejo od stopnje usposobljenosti, zadostne za družbeno udejanjanje, saj izobrazbenega izhodišča niso sposobni nadgrajevati. 


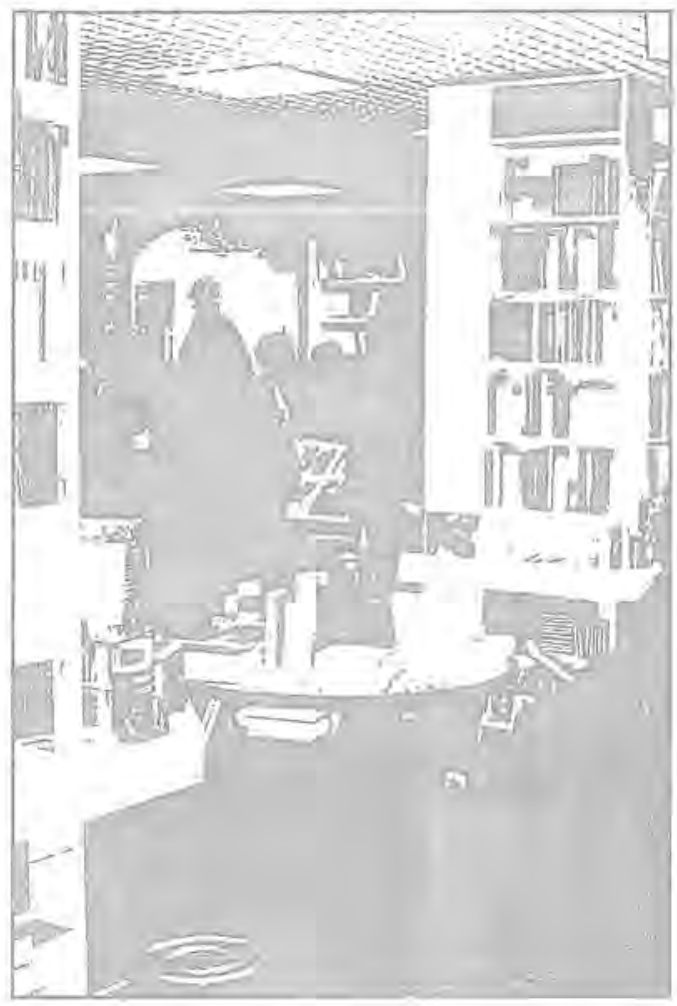

pisnimi spretnostmi.

Siceršnji strukturni problemi družbe se tako odražajo skozi pismenost, ki je svojevrsten družben fenomen (Ahmed, 1992, str. 32).

Funkcionalna pismenost se kaže $v$ vseh segmentih človekovega delovanja in v kakovosti življenja (več o tem: Bindari Hammad in Mulholland, 1992), zato je pomemben pokazatelj splošne socialne pravičnosti pa tudi socialne pravičnosti dostopa do izobraževanja. Na tem mestu je smiselno poudariti, da ne pričakujemo, da je možno razlike, ki smo jim priča, močno zmanjšati ali celo izničiti. Kljub dejstvu, da je "sprememba profila pismenosti v posamezni državi dolgotrajen proces" (Tuijnman, 2001, str. 70), je zaskrbljujoče, da se razlike povečujejo.

Funkcionalna pismenost $\mathrm{z}$ novimi tehnologijami in njihovo uvedbo $v$ vsakdanje življenje ter $\mathrm{z}$ vsako novo spretnostjo, ki jo je treba obvladati, dobiva nove razsežnosti. Tisti, ki nimajo niti dostopa do sredstev, s pomočjo katerih bi lahko svoja znanja obnovili in nadgradili, pospešeno povečujejo svoj zaostanek za onimi, katerih kapacitete se neprestano povečujejo.
Strukturni problemi družbe se izražajo skozi pismenost.

\section{LITERATURA}

Ahmed, M. (1992). Literacy in a larger context. V Wagner, Puchner, (ur.), World literacy in the year 2000. The Annals of the American Academy of Political and Social Science. Newbury Park, London, New Delhi: Sage Publications, str. 32-35.

Bélanger, P., Valdivielso, S. (1997). The amplitude and the diversity of organized adult learning. An overview of adult education participation in industrialized countries. V Bélanger, Valdivielso (ur.), The emergence of learning societies: Who participates in adult learning? Oxford, New York, Tokyo: Pergamon, UNESCO institute for education, str. 1-22.

Berlogar, J. (2000). Pismenost odraslih: vprašanje (pat)etike, politike ali preživetja? V Pečar (ur.), Pismenost, participacija in družba znanja. 4. andragoški kolokvij z mednarodno udeležbo. Ljubljana: Andragoški center Republike Slovenije, str. 116-120.

Bindari Hammad, A. el, Mulholland, C. (1992). Functional literacy, health, and quality of life. V Wagner, Puchner (ur.), World literacy in the year 2000. The Annals of the American Academy of Political and Social Science, Newbury Park, London, New Delhi: Sage Publications, str. 103-120.

Dovžak, K. (1993). Predstavitev programa Usposabljanje za življenjsko uspešnost. V Drugi slovenski posvet Funkcionalna pismenost, Ljubljana, 29. 6. 1993. Slovenski posvet Funkcionalna pismenost. Ljubljana: Andragoški center Republike Slovenije, str. 39-42.

Drofenik, O., Ivančič, A. (1992). Opredelitev koncepta funkcionalne pismenosti in zavedanje problematike o funkcionalni nepismenosti v svetu in pri nas. V 1 . posvet Funkcionalna pismenost, Ljubljana, 9. aprila 1992. Slovenski posvet Funkcionalna pismenost. Ljubljana: Andragoški center Republike Slovenije, str. 1-8.

Drofenik, O. in sod. (1998). Nacionalni program izobraževanja odraslih. Strokovne podlage. Zvezek 1. Razvojne usmeritve. Ljubljana: Andragoški center Republike Slovenije.

Drofenik, O. in sod. (1999). Nacionalni program izobraževanja odraslih. Strokovne podlage. Zvezek 2. Cilji, dejavnosti, utemeljitve. Ljubljana: Andragoški 
center Republike Slovenije.

Education policy analysis 2001. Education and skills. (2001). París: Organisation for Economic Co-operation and Development, OECD.

Ekonomsko ogledalo 2000. (2000). Urad RS za makroekonomske analize in razvoj. www.sigov.si/zmar/ arhiv/letno00/ leo2000.html, poglavje VI.

Erjavec, K. (1999a). Medijska pismenost. Kakšno znanje potrebuje državljan $v$ "medijski družbi"? Andragoška spoznanja, letnik 5, št. 3, str. 55-60.

Erjavec, K. (1999b). Vzgoja za medije. Medijska pismenost in aktivno državljanstvo. Andragoška spoznanja, letnik 5 , št. 4 , str. $39-42$.

Findeisen, D. (1998). Funkcionalna nepismenost in kako jo rešujejo Francozi. Tako kot revščina sta tudi nezaposljivost in $\mathrm{z}$ njo povezana funkcionalna nepismenost ljudi nerešeno vprašanje gospodarskega razvoja. Andragoška spoznanja, letnik 4, št. 3-4, str. 22-28.

Hanžek, M. (2000). Znanje in revక̌čina. V Pečar (ur.), Pismenost, participacija in družba znanja. 4. andragoški kolokvij z mednarodno udeležbo. Ljubljana: Andragoški center Republike Slovenije, 2000, str. 93-97.

Heyneman, S. P. (1992). Universal adult literacy: Policy myths and realities. V Wagner, Puchner (ur.), World literacy in the year 2000. The Annals of the American Academy of Political and Social Science. Newbury Park, London, New Delhi: Sage Publications, str. 27-31.

Ivančič, A. (2001). Zahtevnost dela, pismenost in izobrazba, IB revija za strokovna in metodološka vprašanja gospodarskega, prostorskega in socialnega razvoja Slovenije, letnik 35, št. 2/3, str. 45-54.

Janko Spreizer, A. (1998). Funkcionalna pismenost na prelomu tisocletja. Novejše raziskave in opredelitve pismenosti odraslih. Andragoška spoznanja, letnik 4, št. $3-4$, str. 9-21.

Kelaya, P. (2003). Izobraževanje odraslih in socialno razslojevanje. Diplomsko delo. Ljubljana: samozaložba.

Krajnc, A. (1992). Psiho-socialni vidiki. Pojav in analiza funkcionalne pismenosti. V 1, posvet o Funkcionalni pismenosti, Ljubljana, 9. aprila 1992. Slovenski posvet Funkcionalna pismenost. Ljubljana: Andragoški center Republike Slovenije, str, 9-18.

Krajnc, A. (1993). Funkcionalna nepismenost kot posebno stanje osebnosti in razvoj subkulture. V Drugi slovenski posvet Funkcionalna pismenost, Ljubljana, 29. 6. 1993. Slovenski posvet Funkcionalna pismenost. Ljubljana: Andragoški center Republike Slovenije, str. $1-13$.

Krajnc, A. (2001). Kaj poraja funkcionalno nepismenost? Prva opozorila na funkcionalno nepismenost $v$ Sloveniji. Andragoška spoznanja, letnik 7, št. 1, str. $58-67$.
Literacy skills for the knowledge society. (1997). Further results from the international adult literacy survey, Paris: OECD - Organization for economic cooperation and development in Human Resources Development Canada in Minister of Industry, Canada.

Mirčeva, J. (2000). Participacija odraslih v izobraževanju: vir ali posledica družbene razslojenosti. V Pečar (ur), Pismenost, participacija in đružba znanja. 4. andragoški kolokvij z mednarodno udeležbo. Ljubljana: Andragoški center Republike Slovenije, str. 102-104.

Mirčeva, J., Radovan, M. (2001). Organiziranost: institucionalna ponudba, trajanje, način in financiranje izobraževanja. V Mohorčič Špolar in sod. (ur) Udeležba prebivalcev Slovenije v izobraževanju odraslih. Zbirka Študije in raziskave. Ljubljana: Andragoški center Republike Slovenije, str. 78-101.

Mohorčič Špolar, V. A. in sod. (2001). Udeležba prebivalcev Slovenije v izobraževanju odrastih. Zbirka Študije in raziskave. Ljubljana: Andragoški center Republike Slovenije.

Možina, E. (1999). Kolikó je funkcionalno nepismenih v Sloveniji. Metode merjenja nepismenosti odraslih. Andragoška spoznanja, letnik 5, št. 1, str. 13-26.

Možina, E. (2000). Pismenost odraslih v Sloveniji pozabljeni kapital. V Pečar (ur.), Pismenost, participacija in družba znanja, 4. andragoški kolokvij z mednarodno udeležbo. Ljubljana: Andragoški center Republike Slovenije, 2000, str. 18-41.

OECD (2002). Adult literacy, www.oecd,org/EN/ document/0, EN-document-601-nodirectorate-no-272189!-19,00.html.

Poročilo o človekovem razvoju. Slovenija 2000-2001 (2001). Hanžek, Gregorčic in sod. (ur.). Ljubljana: Urad za makroekonomske analize in razvoj.

Radovan, M. (200I). Ovire odraslih pri vključevanju y izobraževanje. V Mohorčič Š Spolar in sod, (ur.) Udeležba prebivalcev Slovenije v izobraževanju odraslilı. Zbirka Študije in raziskave. Ljubljana: Andragoški center Republike Slovenije, str. 129-141.

Tuijnman, A. C. (2001). Pismenost odraslih v SIoveniji. Izsledki raziskave o pismenosti odraslih v Slovenijt in njihov pomen za politiko izobraževanja. Andragoška spoznanja. Letnik 7, st. 1, str. 68-77. 